e-ISSN: 2686-522X, p-ISSN: 2686-5211

DOI: https://doi.org/10.38035/jafm.v1i5

Received: 04 October 2020, Revised: 13 October 2020, Publish: 04 November 2020 https://creativecommons.org/licenses/by/4.0/

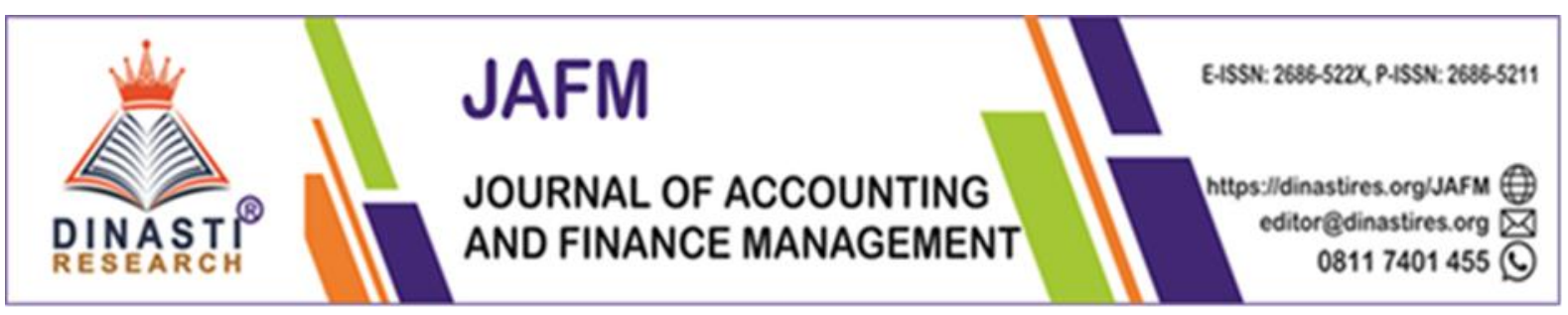

\title{
Audit Committee, Financial Condition, and Firm Performance: Empirical Evidence From Indonesia
}

\author{
Ekawati Jati Wibawaningsih' ${ }^{1)}$, Lidya Primta Surbakti' ${ }^{2)}$ \\ ${ }^{1)}$ Department of Accounting, Faculty of Economics and Business, University Pembangunan \\ Nasional Veteran Jakarta, Jakarta, Indonesia, ekawati.jati@upnvj.ac.id \\ ${ }^{2)}$ Department of Accounting, Faculty of Economics and Business, University Pembangunan \\ Nasional Veteran Jakarta, Jakarta, Indonesia, lidyaprimtasurbakti@ gmail.com
}

Corresponding Author: Ekawati Jati Wibawaningsih ${ }^{1}$

\begin{abstract}
This study has examined the characteristics of the audit committee (size, independence, and expertise) in addition to financial Condition (leverage and firm size) in increasing firm performance. The random effect with panel data regression was applied on 309 firm-year observations of the manufacturing companies listed in the Indonesian Stock Exchange (IDX) for the period of 2016-2018. Return on Assets was used as the measurement of firm performance. This study's results show a significant and positive relationship between firm size with performance and a significant negative relationship between leverage and firm performance. However, the findings show no significant relationship between the characteristics of the audit committee and firm performance. The results of this study have implications for investors, regulators, and market participants. Policy makers might use these findings, especially regarding the characteristics of the audit committee and financial conditions, for improving the performance of the companies in Indonesia.
\end{abstract}

Keywords: Audit Committee, Financial Condition, Firm Performance, Indonesia

\section{INTRODUCTION}

Financial fraud gives a bad image for domestic and foreign investment and also greatly affects a country's economic growth (Bhasin, 2013). Several scandals exist in several companies in the world, such as Satyam, WorldCom, Enron, etc. In Indonesia there have also been several scandals, including Garuda, tbk; Jiwasraya, tbk; Bank Mega; etc. These cases show that the importance of good corporate governance in a company is to produce correct and accurate financial information in making investment decisions.

The Asian Corporate Governance Association (2014) reported that Indonesia had a corporate governance index of 39 out of 52.8, which was the average index for Asian countries 
(Singapore, Hong Kong, Japan, Taiwan, Thailand, China, India, Malaysia, and Korea). Thus, it can be seen that corporate governance in Indonesia has been low when compared to other Asian countries. The Asian Development Bank (ADB) documented the impact and depth of the Asian crisis due to low good corporate governance (Zhuang, et al., 2001). The financial crisis in Asia has been a momentum that has prompted Asia to undertake reforms of corporate governance, including in Indonesia. Good corporate governance is the key to transparency and accountability needed by companies to be able to compete in the business world in all sectors, both national and international. Given this, the Financial Services Authority in Indonesia (OJK) has increased the responsibilities and roles of the audit committee, one of which is to examine financial reports including assets, investments, etc. This study has empirically examined the relationships between company performance and audit committee and financial condition.

This study has examined the effects of the audit committee as measured by the characteristics of the audit committee including size, expertise, and independence on the company's financial performance in proxy leverage and firm size. This study chose a sample of manufacturing companies because it is the largest sector compared to other sectors this shows that manufacturing companies have a significant impact on the Indonesian Stock Exchange (IDX).

Based on the OJK (2014), the audit committee is part of the board responsible for monitoring financial reporting which is also an internal controller capable of reducing agency conflicts amongst the management, shareholders, and stakeholders. According to research conducted by Bouaziz (2012) and Anderson, et al. (2004), they found that the greater the size of the audit committee, the greater the company's performance. In contrast, the research of Amer, et al. (2016) and Aanu, et al. (2014) found that the size of the audit committee had no effect on company performance. The existence of an independent audit committee in a company can reduce the possibility of fraud in the company (Beasley, 1996). Bouaziz and Triki (2012) and Arslan, et al. (2014) found that the existence of an independent audit committee can improve company performance.

Financial condition is a factor that affects company performance, which includes leverage and firm size. Jensen (1986) found that a high level of leverage will reduce the level of company performance. In other words, leverage has a negative relationship with company performance. In contrast, Gondrige, et al. (2012) and Lama (2013) found that the higher the leverage the better the company's performance, and the bigger the company, the better the company's performance.

\section{LITERATURE REVIEW}

The agency theory assumes that the varying interests of the principal and agent can reduce or regulate these interests by providing incentives to the agents that generate the costs of operations (Jensen \& Meckling, 1976; Hill \& Jones, 1992). According to research by Bonazzi and Islam (2007), by providing incentives to agents and monitoring agent activity, the principalwill ensure that the agent acts in the interests of the principal. With the existence of an audit committee being one of the ways to reduce information asymmetry, governance mechanisms, such as audit committees with appropriate characteristics such as expertise, size, and independent experience, are needed to avoid or reduce agent interests and financial 
conditions(Wiseman, Cuevas-Rodríguez, \& Gomez -Mejia, 2012).

\section{Firm Performance}

According to research by Aldamen, et al. (2012), the audit committee contributes to the quality of financial reporting, risk evaluation, and monitoring and thus, improves company performance. Dakhlallh (2020) in his research explained that company performance is influenced by the size of the audit committee, the independence of the audit committee, and the financial expertise of the audit committee. The results of this study support a theory that explains that the size of the audit committee can increase the efficiency of the audit committee. The agency theory states that the independence of the audit committee and the knowledge and ability in the financial sector by the audit committee can improve company performance.

In this study, firm performance was measured using Return of Assets (ROA) (Hansen, 1989; Bontis, et al., 2005; and Zabri, et al., 2016). ROA is the ratio of earnings before interest expenses divided by total assets for the same period. This ratio shows the amount of income generated from the invested assets (Zabri, et al., 2016). The ROA can evaluate the performance of the company and describe the level of efficiency in using the assets for profit (Bontis, et al., 2005). Doan (2020) in his research explained that company performance affects a company's funding decisions.

\section{Audit Committee Size and Firm Performance}

According to Bonazzi and Islam (2007), by monitoring agent activities, it will improve agent performance and prevent possible conflicts of interest, thereby increasing company performance. One of the duties of the audit committee based on the Financial Services Authority Regulation No. 55 / POJK.04.2015 is to review and provide advice to the Board of Commissioners regarding potential conflicts of interest of the Issuer or Public Company. Based on the results of previous research, it states that the size of the audit committee has a significant effect on company performance (Dakhlallh, 2020; Rahman, et al., 2019; Alqatamin, 2018; and Aldamen, et al., 2012).

The size of the Audit Committee in Indonesia is determined based on the Financial Services Authority Regulation No. 55 / POJK.04.2015, which regulates an audit committee consisting of at least three people chaired by an Independent Commissioner and parties from outside a public company. Aldamen, et al. (2012) in their research stated that the number of audit committee members had a negative effect on the company's market performance. This shows that a large number of audit committee members makes its function ineffective. The opposite effect is based on the research results of Dakhlallh (2020) and Rahman, et al. (2019) who stated that the size of the audit committee had a positive effect on company performance. The results of this study support the theory of resource dependency, which explains that the size of the audit committee can increase the efficiency of the audit committee. In Beasly's (1996) study, the audit committee within the company could not reduce the possibility of financial statement fraud. This result is supported by Zhou and Maggina (2018) who reported that there was no relationship between the audit committee and company performance. $\mathrm{H}_{1}$ : The size of the Audit Committee has a positive effect on company performance.

\section{Audit Committee Expertise and Firm Performance}

Firm performance may be identified from internal control weaknesses if the Audit 
Committee has less expertise (Zhang, et al., 2007). The agency theory states that knowledge and ability in the financial sector by the audit committee can improve company performance (Dakhlallh, 2020). The agency theory assumes that the varying interests of the principal and agent can reduce or regulate these interests by providing incentives to agents and thus, creating the costs of the operations (Jensen \& Meckling, 1976; Hill \& Jones, 1992).

Based on the results of research by Aldamen, et al. (2012), it was stated that the audit committee with a lot of experience and financial expertise has a positive effect on firm performance. Expertise in an audit committee can provide better financial reporting, so as to improve company performance. This result is in accordance with the research of Dakhlallh (2020) who reported that the financial expertise of the audit committee had a positive effect on firm performance. In contrast, Alqatamin's (2018) stated that there was no correlation between the expertise of the audit committee and firm performance.

$\mathrm{H}_{2}$ : The expertise of the audit committee has a positive effect on firm performance.

\section{Audit Committee Independence and Firm Performance}

The agency theory explains that the independence of the audit committee can improve firm performance (Dakhlallh, 2020). According to Bronson, et al. (2009) shows that the independence of the audit committee can provide reliable company information to the public. Based on the Financial Services Authority Regulation No. 55 / POJK.04.2015 article 9, it states that the Audit Committee acts independently in carrying out its duties and responsibilities. The independence of the audit committee can reduce fraudulent financial statements, which leads to an increase in firm performance (Bansal \& Sharma, 2016). One of the things that can affect the independence of the members of the audit committee is the length of time in the office of the audit committee (Aldamen, et al, 2012). Based on Alqatamin's, et al. (2018), the independence of the audit committee had a positive effect on firm performance.

$\mathrm{H}_{3}$ : The independence of the audit committee has a positive effect on firm performance.

\section{Leverage and Firm Performance}

Leverage is the ratio between long-term debt and total company debt. If the company's agency costs are reduced due to higher levels of debt, then the capital structure will have a significant relationship with firm performance (Jensen, 1986). Based on Bansal and Sharma (2016), Leverage had a negative effect on firm performance. This suggests that a high amount of debtcan reduce firm performance. These results are supported by research by Ibhagui and Olokoyo, 2017, which stated that leverage had a negative effect on firm performance, measured by the return of assets (ROA).

$\mathrm{H}_{4}$ : Leverage has a negative effect on firm performance.

\section{Firm Size and Firm Performance}

A larger company, as measured by the total assets held, is less likely to default on its debt obligations (Sheikh, et al., 2011). Several studies, such as Chhibber and Majumdar (1999), Gleason, et al. (2000), and Ehikioya (2009), reported a positive relationship between firm sizeand firm performance.

$\mathrm{H}_{5}$ : Firm size has a positive effect on firm performance. 


\section{RESEARCH METHODS}

The sample of this research 309 observations of firm-years of manufacturing companies listedon the Indonesian Stock Exchange (IDX) for the 2016 to 2018 period. Dependent and independent variable data to avoid the influence of outliers were won at the 3 per cent level; this is in accordance with the recommendations of Surbakti and Samosir (2019). This study has aimed to determine the effects of the audit committee (independence, expertise, and size) and financial condition (leverage and firm size) on firm performance. Where firm performance was measured by return on assets (FIRMP); audit committee was measured by size (ACSIZE), expertise (ACEXPERT), and independence (ACIND); and financial condition was measured by leverage (LEV) and firm size (FSIZE). Panel data was used in this study and the random effects panel data regression model was used to analyse the relationship between the audit committee and financial conditions on firm performance.

The following regression models were used in this study:

$$
\text { FIRMP }_{i t}=\beta_{0}+\beta_{1} \text { ACSIZE }_{i t}+\beta_{2} A C E X P E R T_{i t}+\beta_{3} A C I N D_{i t}+\beta_{4} L_{E V} V_{i t}+\beta_{5} F_{S I Z E}+e_{i t}
$$

Where,

\section{Table 1. Variable Measurement}

\begin{tabular}{ll}
\hline FIRMP & $\begin{array}{l}\text { Firm performance was measured using Return on Assets, i.e., the ratio of total } \\
\text { income and total assets }\end{array}$ \\
\hline ACSIZE & $\begin{array}{l}\text { Number of audit committee members } \\
\text { The proportion of audit committee members who had an accounting background or } \\
\text { ACEXPERT }\end{array}$ \\
finanial experience \\
ACIND & $\begin{array}{l}\text { The proportion of independent members from the total number of audit committee } \\
\text { members }\end{array}$ \\
LEV & $\begin{array}{l}\text { Ratio of debt to equity } \\
\text { The natural logarithm of total assets }\end{array}$ \\
\hline
\end{tabular}

\section{FINDINGS AND DISCUSSION}

\section{Descriptive Statistics and Analysis}

Table 2 shows that the average company performance was 0.044 or 4.4 percent in the public companies in Indonesia. The average company had three members of the audit committee and 2 members who were experts, and the independence of the audit committee was at 94.76 percent, which was more than the minimum requirement over Bapepam-LK (2012). Based on Table 2, the mean of leverage was 50.12 per cent, and the average size of the company was $1.93 \mathrm{e}+08$ on the IDX.

\section{Table 2. Descriptive Statistics}

\begin{tabular}{lccccc}
\hline Variable & Obs & Mean & Std. Dev. & Min & Max \\
\hline FIRMP & 309 & .0445359 & .0818721 & -.134014 & .2905089 \\
ACSIZE & 309 & 3.058252 & .2346001 & 3 & 4 \\
ACEXPERT & 309 & 2.055016 & .7474301 & 0 & 3 \\
ACIND & 309 & .9476807 & .1321205 & .3333333 & 1 \\
LEV & 309 & .5012954 & .3036041 & .0929256 & 1.571057 \\
FSIZE & 309 & $1.93 \mathrm{e}+08$ & $1.85 \mathrm{e}+09$ & 1587 & $1.97 \mathrm{e}+10$ \\
\hline
\end{tabular}

\section{Results and Discussion}

Random effect regression was used and as a control for autocorrelation, heteroscedasticity, and multicolinearity. For the dependent variable regression model (FIRMP), the model was fit andsignificant at the 0.00 level $(\mathrm{F}$-value $=37.09, \mathrm{R} 2=0.0804)$. Table 4 shows that ACSIZE had no significant relationship with FIRMP $(t=0.59, p>0.10)$. 
The results do not support the agency theory, where ACSIZE could not improve firm performance. Thus, hypothesis 1 was rejected. Table 5 shows that the ACIND and ACEXPERT audits had no significant effect on FIRMP. This result also shows that H2 and H3 were rejected. The results of this study are in contrast to the findings of Dakhlallh (2020) and Alqatamin (2018) which found that ACIND and ACEXPERT could improve company performance and reduce agency cost in the company

Table 3. Multiple Regression

Results

\begin{tabular}{lcccc}
\hline Variables & Coef. & Std. Err. & t-Statistic & Prob \\
\hline cons & .0201844 & .0693592 & 0.29 & 0.771 \\
\hline ACSIZE & .0110346 & .0188195 & 0.59 & 0.558 \\
\hline ACEXPERT & .0001933 & .0057616 & 0.03 & 0.973 \\
\hline ACIND & -.0258728 & .0327005 & -0.79 & 0.429 \\
\hline LEV & -.0997212 & .0142266 & -7.01 & $0.000^{* * *}$ \\
\hline FSIZE & .0043746 & .0023692 & 1.85 & $0.065^{*}$ \\
\hline F-value & & & 37.09 \\
\hline Sig & & & 0.0000 \\
\hline R-squared & & & 0.0804 \\
\hline $\mathbf{N}$ & & & 309
\end{tabular}

Leverage was found to have a significant negative relationship with FIRMP $(t=-7.01, p$ $<0.01)$. This resulted in $\mathrm{H} 4$ being accepted; The amount of corporate leverage will increase firm performance and thus supports the agency theory. This study shows that companies that have a low level of leverage will have a good firm performance. This result is also supported by the findings of Olokoyo (2017) and Bansal and Sharma (2016). The results of this study indicate a significant and positive relationship between FSIZE and FIRMP $(t=1.85, p<0.10)$. Thus, hypothesis H5 was accepted. A significant relationship has been shown by this finding in that large companies show better firm performance (Ehikioya, 2009 \& Gleason, et al., 2000). This is because, larger companies focus more on strategies to protect the interests of shareholders Adams (2003), so that the results of this study can accept agency theory.

The findings of this study should be of interest to creditors, policy makers, managers, and investors, especially with regard to issues related to firm performance, audit committee characteristics, and financial conditions. In relation to the dimensions of audit committee characteristics and financial conditions, the findings indicate a practical contribution that financial conditions have an effect on company performance in companies listed on the Indonesian Stock Exchange (IDX).

\section{CONCLUSION AND SUGESTION}

This study used return on assets in detecting the discretionary factors in assessing the firm performance in companies listed on the Indonesian Stock Exchange. In addition, this study has provided evidence of their financial conditions, including leverage and firm size, which significantly affected the level of firm performance. However, the findings of this paper also reveal that some characteristics of the audit committee (size, independence, and expertise) may not always be contributing factors to improving performance. Like other studies, this study is also limited in scope to the manufacturing companies registered in Indonesia for a certain threeyear period (2016 to 2018). It is recommended that further research 
should try to examine other characteristics of audit committees, specific to firms, and their uses for capturing monitoring of the corporate governance mechanisms.

\section{REFERENCE}

Mohammed, B. H., Flayyih, H. H., Mohammed, Y. N., \& Abbood, H. Q. (2019). The effect of audit committee characteristics and firm financial performance: An empirical study of listed companies in Iraq stock exchange. Journal of Engineering and Applied Science, 14(4), 4919-4926.

Amer, M. (2016). Measuring the effect of the board of directors and audit committee characteristics on firm financial performance in Egypt (Doctoral dissertation, Cardiff Metropolitan University).

Aldamen, H., Duncan, K., Kelly, S., \& McNamara, R. (2020). Corporate governance and family firm performance during the Global Financial Crisis. Accounting \& Finance, 60(2), 1673-1701.

Alqatamin, R. M. (2018). Audit committee effectiveness and company performance: Evidence from Jordan. Accounting and Finance Research, 7(2), 48.

Anderson, R. C., Mansi, S. A., \& Reeb, D. M. (2004). Board characteristics, accounting report integrity, and the cost of debt. Journal of accounting and economics, 37(3), 315-342.

Arslan, M., Zaman, R., Malik, R. K., \& Mehmood, A. (2014). Impact of CEO duality and audit committee on firm performance: A study of oil \& gas listed firms of Pakistan. Research Journal of Finance and Accounting, 5(17), 2222-1697.

Bansal, N., \& Sharma, A. K. (2016). Audit committee, corporate governance and firm performance: Empirical evidence from India. International Journal of Economics and Finance, 8(3), 103.

Beasley, M. S. (1996). An empirical analysis of the relation between the board of director composition and financial statement fraud. Accounting review, 443-465.

Ben Barka, H., Legendre, F. Effect of the board of directors and the audit committee on firm performance: a panel data analysis. J Manag Gov 21, 737-755 (2017).

Bhasin, M. L. (2013). Corporate accounting fraud: A case study of Satyam Computers Limited. Open Journal of Accounting, 2, 26-38.

Bonazzi, L., \& Islam, S. M. (2006). Agency theory and corporate governance: a study of the effectiveness of the board in their monitoring of the CEO. Journal of Modeling in Management, 2 (1), 7-23.

Bontis, N., Wu, S., Chen, M. C., Cheng, S. J., \& Hwang, Y. (2005). An empirical investigation of the relationship between intellectual capital and firms' market value and financial performance. Journal of intellectual capital.

Bouaziz, Z., \& Triki, M. (2012). The impact of the presence of audit committees on the financial performance of Tunisian companies. International Journal of Management \& Business Studies, 2(4), 57-64.

Bronson, S. N., Carcello, J. V., Hollingsworth, C. W., \& Neal, T. L. (2009). Are fully independent audit committees really necessary?. Journal of Accounting and Public Policy,28(4), 265-280.

Chhibber, P. K., \& Majumdar, S. K. (1999). Foreign ownership and profitability: Property rights, control, and the performance of firms in Indian industry. The Journal of Law and Economics, 42(1), 209-238.

Dakhlallh, M. M., Rashid, N., Abdullah, W. A. W., \& Al Shehab, H. J. (2020). Audit Committee and Tobin's Q As A Measure of Firm Performance among Jordanian Companies. Jour of Adv Research in Dynamical \& Control Systems, 12(1).

De Oliveira Gondrige, E., Clemente, A., \& Espej, M. M. D. S. B. (2012). Composition of the board and firm value of brazilian public companies. Brazilian Business Review, 9(3), 
71- 93.

Doan, T. (2020). Financing decision and firm performance: Evidence from an emerging country. Management Science Letters, 10(4), 849-854.

Ehikioya, B. I. (2009). Corporate governance structure and firm performance in developing economies: evidence from Nigeria. Corporate Governance: The international journal of business in society.

Gleason, K. C., Mathur, L. K., \& Mathur, I. (2000). The interrelationship between culture, capital structure, and performance: evidence from European retailers. Journal of business research, 50(2), 185-191.

Hansen, G. S., \& Wernerfelt, B. (1989). Determinants of firm performance: The relative importance of economic and organizational factors. Strategic management journal, $10(5), 399-411$.

Hill, C. W., \& Jones, T. M. (1992). Stakeholder-agency theory. Journal of management studies, 29(2), 131-154.

Ibhagui, O. W., \& Olokoyo, F. O. (2018). Leverage and firm performance: New evidence on the role of firm size. The North American Journal of Economics and Finance, 45, 5782.

Jensen, M. C. (1986). Agency costs of free cash flow, corporate finance, and takeovers. The American economic review, 76(2), 323-329.

Jensen, M. C., \& Meckling, W. H. (1976). Theory of the firm: Managerial behavior, agency costs and ownership structure. Journal of financial economics, 3(4), 305-360.

Rahman, M. M., Meah, M. R., \& Chaudhory, N. U. (2019). The impact of audit characteristics on firm performance: an empirical study from an emerging economy. The Journal of AsianFinance, Economics and Business (JAFEB), 6(1), 59-69.

Sheikh, N. A., \& Khan, M. I. (2016). Effects of excess cash, board attributes and insider ownership on firm value: evidence from Pakistan. Australasian Accounting, Business and Finance Journal, 10(1), 29-39.

Surbakti, L. P., \& Samosir, H. E. S. (2019) Earnings Quality and the Effect of Internal Monitoring Corporate Governance: Evidence from Indonesia.

Tripathy, S., \& Shaik, A. (2020). Leverage and firm performance: Empirical evidence from Indian food processing industry. Management Science Letters, 10(6), 1233-1240.

Wiseman, R. M., Cuevas-Rodríguez, G., \& Gomez-Mejia, L. R. (2012). Towards a social theory of agency. Journal of management studies, 49(1), 202-222.

Zabri, S. M., Ahmad, K., \& Wah, K. K. (2016). Corporate governance practices and firm performance: Evidence from top 100 public listed companies in Malaysia. Procedia Economics and Finance, 35, 287-296.

Zhuang, J., Edwards, D., \& Capulong, M. V. A. (2001). Corporate Governance \& Finance in East Asia: A Study of Indonesia, Republic of Korea, Malaysia, Philippines and Thailand. Asian Development Bank.

Zhang, Y., Zhou, J., \& Zhou, N. (2007). Audit committee quality, auditor independence, and internal control weaknesses. Journal of accounting and public policy, 26(3), 300-327.

Zhou, H., Owusu-Ansah, S., \& Maggina, A. (2018). Board of directors, audit committee, and firm performance: Evidence from Greece. Journal of International Accounting, Auditingand Taxation, 31, 20-36. 